Canadian Studies in Population, Vol. 32.2, 2005, pp. 257-270

\title{
Aging Amongst Immigrants in Canada: Population Drift
}

\author{
Douglas Durst \\ Faculty of Social Work \\ University of Regina \\ Regina, Saskatchewan, Canada
}

\begin{abstract}
In Canada, two interesting demographic trends have been underway: an aging population and a growth based upon immigration. These patterns combine to form a new group that seems to have evaded notice. According to the 2001 Census of Canada, immigrants are older than the national average and almost $31 \%$ of the immigrants from Europe are over 65 years of age. Of the total senior population, $28.4 \%$ are immigrants with $5 \%$ of Asian descent. Overall, $7.2 \%$ of the senior's population is a visible minority. These patterns have implications for policy development and service delivery. As immigrants age in Canada, they will have very different expectations for services than non-immigrants and immigrants who aged in their home country. This paper offers recommendations for policy planners and service providers in health and social welfare services.
\end{abstract}

Key Words: Immigrants, aging, ethnicity 
Douglas Durst

\section{Résumé}

Au Canada, deux tendances démographiques intéressantes se développent : une population vieillissante et une croissance due à l'immigration. Ces tendances se combinent et forment un nouveau groupe qui a passé inaperçu jusqu'à présent. Selon le Recensement du Canada de 2001, les immigrants sont plus âgés que la moyenne nationale et presque $31 \%$ des immigrants en provenance d'Europe on plus de 65 ans. Parmi la totalité de la population des personnes âgées, 28.4\% sont des immigrants et 5\% sont en provenance d'Asie. $7.2 \%$ de la population des personnes âgées appartiennent à une minorité visible. Ces tendances ont des implications au niveau du développement de polices et des prestations de services. Au fur et à mesure que les immigrants vieillissent, leurs attentes au niveau des services seront très différentes de celles des non-immigrants et des immigrants qui ont vieilli dans leur pays d'origine. Cet article propose des recommandations pour les responsables et les prestataires de services dans les domaines de la santé et du bien-être social.

Mots-clés: Immigrants, vieillir, ethnicité

\section{Introduction}

In Canada, two interesting demographic trends have been silently progressing: an aging population and a population growth based upon immigration. These patterns combine to form a new group of aging immigrants that seems to have evaded the notice of most sociologists and demographers. For the most part, gerontological research has failed to recognize ethnicity or culture as a relevant variable and research on ethnicity has failed to recognize aging as a relevant variable. As recently as 1980, the public policy report called A Profile of Canada's Older Population neglected ethnicity as a subject matter. Although social researchers have always been interested in ethnicity and aging, little consideration has been given to the combined impact of these two intersecting variables.

Over a hundred years ago, Chancellor Otto von Bismark of Germany implemented his retirement and pension programs, and persons aged 65 years were effectively near the end of their lives. Over time, life expectancy has increased and a 65 year old can expect to live another 20 years. Yet, Bismark's benchmark for retirement has not changed. Anyone 65 years of age or older is considered in a broad nebulous category as "senior". Curiously, "old age" is 
Aging amongst Immigrants in Canada: Population Drift

frequently considered as a single stage of life. A retired individual is "a retired senior" regardless of whether he is 65 or 95 years of age, representing a 30-year span. It could be considered as similar to comparing a 5 year old to a 35 year old or a 20 year old to a 50 year old. The issues facing each age group are very different and do not allow for simple comparisons. In order to address this problem, Suzman and Riley (1985) offer three stages of persons over 65: the young-old (65 to 75/80), the old-old (75/80 to 90 ) and the very-old or frail old (over 85/90).

In spite of these categories, chronological age is a weak criterion for clustering or classifying individuals. It does not allow for individual and cultural diversity in economic, health and social capacities and deficiencies. For example, persons of Aboriginal ancestry are understood to "age" earlier and often someone as young as 50 years of age is viewed as "senior". Recognizing its arbitrary nature, these age categories do allow statistical clustering and the application and analysis of census data.

Except perhaps in the first 5 years of life, the physical and mental changes during the last thirty years of life are more dramatic than at any other period. Suzman and Riley's (1985) three groups differ in important and significant ways but they all experience loss. They experience financial loss (income, savings, health costs), physical loss (strength, hearing, seeing, mobility), emotional loss (family, friends, death, isolation, loneliness) and mental loss (memory, cognitive, emotional control). The young-old often remain active and normally, enjoy full and rewarding roles and activities. For some, this stage can be extremely expressive and creative. They are more like "middle-aged" but with more time! The old-old experience increasing loss but can enjoy fulfilling lives with environmental and social supports. The very old are often physically and mentally impaired and need extensive supports sometimes from formal institutions (Schaie \& Willis, 1998). They are often referred to as the "frail elderly".

The study of "immigrants" is complex and becomes even more confusing when considering aging. For example, researchers often aggregate refugees and immigrants together and ignore the different classes of both immigrants (Family, Economic, Other) and refugees (Assisted, Sponsored, Asylum). Often those persons under economic classes immigrated when they were young or young adults. For example, the universities and health care fields have recruited individuals who have diverse backgrounds. Many of the individuals hired in the expansion of the universities in the 70s are at or near retirement and enter the seniors group. They have raised their families and Canada is now "home" even though they may have thought about returning to their country of origin when they first arrived in Canada. They do not return and make significant impacts in 
our communities. Their situations can be very different than the elderly who recently arrived in Canada. Under the Family Class, immediate families sponsored their parents and/or grandparents. Many from regions such as Asia do not speak English or French and are socially and economically dependent upon their children. They can be very isolated. These individuals will be older and have different social and health needs than business immigrants in the economic class. These family sponsored elderly will require different policies and programs. As immigrants age, Canada is experiencing an increase in the old-old immigrant group from two sources. Many immigrants and refugees aged in Canada and others immigrated as a "senior", having experienced most to their aging in their country of origin.

For example, one can imagine the differences between two senior immigrants/refugees from Hong Kong. The previous Governor General of Canada, the Right Honourable Adrienne Clarkson, immigrated as a "refugee" child during the Second World War. She grew up in Canada and experienced Canadian society throughout her entire life. Her situation is very different than an aged grandmother who immigrated under the family reunification program at the age of 70 years old. Unfortunately, statistical data usually combine these individuals as "foreign-born Chinese". It is important that researchers, policy analysts and programmers do not aggregate these differences and make false assumptions and generalizations; thereby stereotyping and missing the diversity within the group.

The issues, pertaining to visible minorities, further complicates an already complex situation. For example, many European immigrants may be considered "mainstream", visible minority or invisible minority and therefore, generalizations may be false or misleading. Interestingly, in 2001 the province of Saskatchewan had the largest percentage of foreign-born immigrant population over the age of 75 years. It had $53 \%$ of the over 75 population as foreign born from Germany, Ukraine, Norway, Hungary, and Poland. The large migration to the west in the 1920s has left its impact. Newfoundland and Labrador has the least percentage of over 75 as foreign-born at only $2 \%$ (Canada, 2005).

Gerontological research on minority groups has generally applied three conceptual frameworks: multiple jeopardy, leveling, and the life course perspective (Novak, 1997). In multiple jeopardy, researchers use variables such as age, sex, income, education, disability, and ethnicity to classify individuals. Broadly speaking, each of these variables can be compared to mainstream society and since older immigrants or visible minorities have poorer health and lower incomes than the mainstream group, they experience the multiple "jeopardy" of their "status". Not all immigrants are "visible minorities" and 
Aging amongst Immigrants in Canada: Population Drift

many of the elderly immigrants can be considered part of the mainstream society. In addition, because women live longer, the percentage of women increases over time. So the "jeopardy" of age, sex, visible minority, ethnicity, language, health, income, and so on compound and disadvantage the individual. If a cross section of the sample is studied, it neglects the change over time that the group experiences. If the group starts out poor in both wealth and health, then the group will remain so later in life. If multiple jeopardy affects only the lower class visible minority then it is only social class rather than ethnic status that creates the multiple jeopardy (Novak, 1997). This theoretical approach has limitations.

Other research has suggested that there is a "leveling" and converging of indicators as people age. The disparity in the quality of life indicators between ethnic seniors and the dominant group diminishes as they age because of such variables as strong family connections and supports. If an ethnic minority person who is middle-aged has a low income, their income changes little as they move into retirement and from employment income and onto income support programs (Novak, 1997).

However, both the multiple jeopardy and leveling approaches miss the diversity within minority groups and they also miss the effects of earlier life. For example, refugees and immigrants from People's Republic of China and Hong Kong come from very different cultures yet are frequently clustered together for statistical purposes. One could further complicate the demographics by adding ethnic Chinese who have come to Canada from Indonesia or Vietnam. Furthermore, recent immigrants and long term immigrants have different experiences and may not be comparable but are listed as "Chinese". In addition, some refugees, such as many from Central America, have experienced trauma and torture. These and other trauma will influence them in subtle but important ways limiting the value of simple comparisons. The life experiences and subjective qualitative perspectives are major influences of integration, life satisfaction, mental health and emotional stability (Novak, 1997). Hence, the life course perspective offers a valuable framework in completing research on aging immigrants and refugees. Often trauma that occurred decades ago resurfaces in frail elderly who are suffering from cognitive dysfunctions or emotional problems.

In recent years, there has been a growing interest in researching aging and ethnicity. Most of the published social research has focused on a single ethnic group and are generally categorized under Asian, Hispanic, African American and Native American (for example: Olson, 2001). Ethnic-religious groups such as Jewish, Mormon or Amish have also been researched as well as special groups such as gays and lesbians, or rural elderly (for example: Gelfand, 2003, 
Gelfand and Barresi, 1987; Olson, 2001). Often the contributors present a "case study" type of research that attempts to give an overview of the cultural group and its experiences in aging. Normally, they discuss topics such as health, income, housing and sometimes satisfaction. There is considerable Canadian research on Asian elderly, mainly Chinese (for example: Lai, 2000; MacKinnon et al. 2001). There is little comparative research between mainstream society and ethnic groups or between ethnic groups. A few American studies cluster Asian, African American (Black), Hispanic (Latino), and Native American and compare them under social determinants such as income, housing, health and so on (for example: Gelfand, 2003; Manuel \& Reid, 1982; Markides \& Mindel, 1987). There is little conceptual literature that attempts to encompass the overall field of study. Although over 20 years old, the chapters, on theoretical orientations by Rey, Lipman and Brosky (Manuel, 1982), are helpful as are Driedger \& Chappell (1987), Gelfard (2003) and Ujimoto (1987). The danger of applying models and aggregating data from different groups is a form of reductionism and invites generalizations and assumptions, which may be false or misleading. For example, the role of family as an emotional and social support may look different between groups and within categories.

Recent research on inclusion and integration offer promising frameworks that are culturally sensitive and relevant to this population. Freiler's (2001) inclusion model was developed to research women in poverty can be appropriately used as a model for aging and ethnicity.

Social research on aging and ethnicity is complex. Issues on age categories, immigrant status, length of residency, age at immigration, ethnic background and history and familial relationships complicate the research and limit generalizations. Furthermore, language and cultural barriers and customs restrict access. Burton \& Bengtson (1982) and Durst (1996) identify some of the stumbling blocks and barriers to researching aging and ethnicity.

\section{Current Situation in Canada}

In 2001, Canada reported $13.0 \%$ of its population over 65 years of age and over with $5.1 \%$ of its population as "old" (75+). There were marked differences between provinces and territories with Nunavut at a low of $2.5 \%$ and Saskatchewan with a high of $14.8 \%$ senior populations (Canada 2004). Like most developed countries, Canada is experiencing an aging population due to an increasing life expectancy and a declining birth rate. Much of the population growth is now attributed to immigration. The seniors' population is expected to continue to grow and Statistics Canada projects the percentage of seniors to be $23 \%$ of all Canadians by 2041. The greatest growth will be in the old-old and 
Aging amongst Immigrants in Canada: Population Drift

very-old ranges. The senior population is predominantly female with $57 \%$ of the over 64 age group women. The percentage increases to $60 \%$ for the old-old (7584 years of age) and $70 \%$ for the very-old (over 85 ).

Table 1 presents the percentage of senior immigrants by place of birth in two age categories (65-74 and 75 and over years of age). Almost $19 \%$ of the immigrant population in Canada is over 65 and this number is much higher than the national average of $12.2 \%$. And almost $31 \%$ of the immigrants from Europe are over 65 years of age. The European immigrants are an aging population. The senior population from Eastern Asia (mostly Hong Kong, China, Taiwan) is $13 \%$ of total immigrants from this region. Caribbean immigrants are also older than other immigrant groups and near the national average at $11.7 \%$. The assumption that "immigrants" are young is not supported. Canada has larger numbers of immigrants from diverse backgrounds and the senior population is mirroring the Canadian mosaic. By percentage, the youngest group is from Central and South American (6.7\%). Not surprisingly the African and South East Asia (Thailand, Laos, Vietnam) are still fairly young at about $8.0 \%$ each.

Table 1

Senior Immigrants by Place of Birth for Canada: 2001

\begin{tabular}{lccc}
\hline Place of Birth & $\begin{array}{c}\mathbf{6 5 - 7 4} \text { Years } \\
(\mathbf{\%})\end{array}$ & $\begin{array}{c}\mathbf{7 5} \text { and over } \\
\mathbf{( \% )}\end{array}$ & $\begin{array}{c}\mathbf{6 5} \text { and over } \\
(\mathbf{\%})\end{array}$ \\
\hline Total Seniors & $\mathbf{7 . 1}$ & $\mathbf{5 . 1}$ & $\mathbf{1 2 . 2}$ \\
$\quad \mathbf{6 5}$ and over & & & \\
& & 7.8 & 18.9 \\
Total Immigrant & 11.1 & 13.4 & 30.7 \\
Europe & 17.3 & 2.1 & 6.7 \\
Central /South & & 3.4 & 11.4 \\
America & 4.6 & 2.5 & 8.0 \\
$\quad$ Caribbean & 7.0 & 3.4 & 9.7 \\
Africa & 5.5 & 4.8 & 13.0 \\
Asia & 6.5 & 2.8 & 7.9 \\
$\quad$ Eastern Asia & 8.2 & 3.3 & 8.5 \\
Southeast Asia & 5.1 & & \\
$\quad$ South Asia & 5.2 & & \\
& &
\end{tabular}

Statistics Canada, 2001 Census of Canada 
Douglas Durst

However since many South East Asians came to Canada as refugees during the Vietnam civil war, their senior population is expected to grow.

Table 2, Senior Immigrants and Place of Birth, "re-jigs" the numbers to show percentages from place of birth in the total population of the Canadian Seniors population. Some interesting patterns emerge. Of the total senior population reported in 2001, 28.4\% are immigrants (up from 16.9\% in 1981) and $19.4 \%$ of all seniors are from Europe. However, immigration patterns from Asia show, in fact, that $5.4 \%$ (one in twenty) seniors in Canada are Asian and $4.4 \%$ are south Asian! These Asian seniors are concentrated in the major cities but are present throughout Canada. Overall, $7.2 \%$ of the senior's population is a visible minority that is a significant increase from 1996 when it was $6 \%$.

Table 2

Senior Immigrants by Place of Birth

Percentage of Canadian Seniors for Canada: 2001

\begin{tabular}{|c|c|c|c|}
\hline Place of Birth & $\begin{array}{c}\text { 65-74 Years } \\
(\%)\end{array}$ & $\begin{array}{c}75 \text { and over } \\
(\%)\end{array}$ & $\begin{array}{c}65 \text { and over } \\
(\%)\end{array}$ \\
\hline $\begin{array}{l}\text { Total Seniors } \\
65 \text { and over }\end{array}$ & 58.1 & 41.9 & 100.0 \\
\hline Total Non-Immigrant & 71.2 & 71.7 & 71.4 \\
\hline Total Immigrant & $\begin{array}{c}28.6 \\
\mathbf{1 0 0 . 0}\end{array}$ & $\begin{array}{c}28.0 \\
100.0\end{array}$ & $\begin{array}{c}28.4 \\
\mathbf{1 0 0 . 0}\end{array}$ \\
\hline $\begin{array}{l}\text { Europe } \\
\text { Central /South }\end{array}$ & 18.8 & 20.2 & 19.4 \\
\hline America & 0.7 & 0.4 & 0.6 \\
\hline Caribbean & 1.0 & 0.7 & 0.8 \\
\hline Africa & 0.7 & 0.5 & 0.6 \\
\hline Asia & 6.1 & 4.5 & 5.4 \\
\hline Eastern Asia & 2.9 & 2.3 & 2.6 \\
\hline Southeast Asia & 1.1 & 0.9 & 1.0 \\
\hline South Asia & 1.5 & 0.9 & 1.2 \\
\hline
\end{tabular}

Statistics Canada, 2001 Census of Canada 
Aging amongst Immigrants in Canada: Population Drift

The Chart below, Percentage of Senior Immigrant by Continent, shows that $68 \%$ of all Immigrant Seniors are originally from Europe and that $19 \%$ (one in five) come from Asia. The face of immigrant seniors is changing.

Figure 1

Percentage of Immigrant Seniors by Place of Origin for Canada: 2001

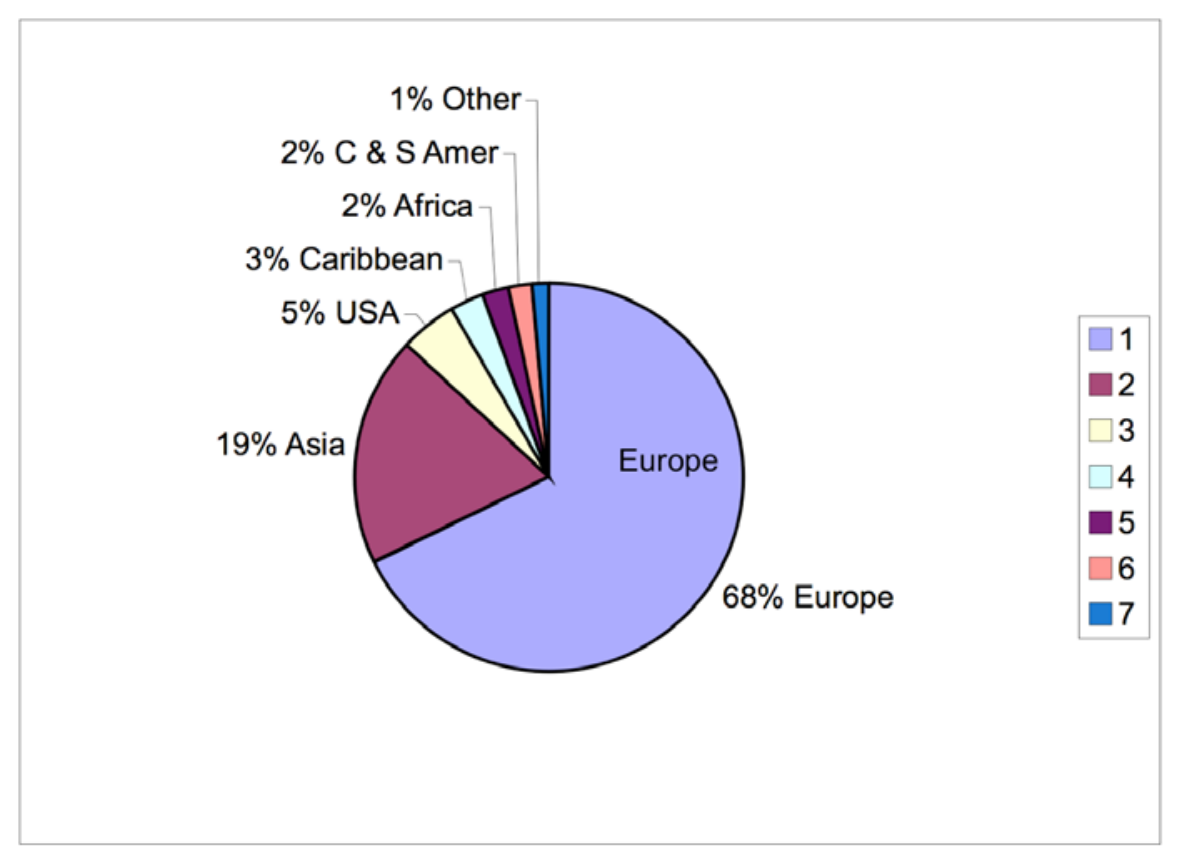

Statistics Canada, 2001 Census of Canada

The Canadian government provides two major income security programs for seniors that many immigrants can access. If they have been in Canada for 10 years, all immigrant seniors (over 65 years of age) are eligible for The Old Age Security program that provides a modest pension. If the senior immigrated at aged 62 then they could be eligible for benefits at aged 72 regardless if they have ever been employed in Canada. If the senior has a low-income, he/she may 
Douglas Durst

be eligible for other benefits as early as age 60 , providing he/she met the 10 -year requirement.

Canada has international social security agreements with many countries to help people qualify for benefits from either country. An agreement may allow periods of contribution to the other country's social security system (or, in some cases, periods of residence abroad) to be added to periods of contribution to the Canada Pension Plan in order to meet minimum qualifying conditions. For example, these agreements would allow a citizen of Germany to access the Canada Pension Plan, including retirement, disability and survivor benefits in Canada. These agreements are with developed countries that have existing income programs for seniors and although it is rare, there have been individuals who have immigrated specifically to "retire" in Canada. It may seem strange to retire in country with snowy and cold winters, but for some immigrants it provides the opportunity to live near adult children in their children's new country. For others, it means escaping the crowded, congested and expensive lifestyle of European cities.

For those seniors who immigrated late in life, they may find that they are exclusively financially dependent upon their sponsoring family. Under the family reunification program, they have sold their businesses, homes or farms and moved to Canada to live under their children's care, often providing care for their grandchildren. These arrangements can be quite traumatic and stressful for once they held status and independence and, now they face loneliness and isolation (MacKinnon, Gien \& Durst, 2001). In leaving their homeland, they give up their rich cultural heritage, community connections and life-long relationships, experiencing a "status discrepancy". Although living in comfortable spacious houses, they describe their children's home as a "golden prison".

\section{Issues and Developing Needs}

As the demographics shift there is a need to better understand and appreciate the diversity among the senior population. In recent years, there has been significant change since Driedger and Chappell published their important work, Aging and Ethnicity: Toward an Interface (1987). Efforts to improved understanding should be developed throughout society, in all sectors. There is a need for further research and implications for policies and programs but researching ethnic aging requires careful planning and thought to ensure cultural relevancy (Durst, 1996). The Prairie Centre of Excellence for Research on Immigration and Integration, a Canadian Metropolis Site, recognized the paucity of research in this field and funded a Social Domain exploratory study. The study is holistic 
Aging amongst Immigrants in Canada: Population Drift

in the sense that it considers the senior immigrant as a total person with social, economic, physical, emotional and spiritual needs. Using both qualitative and qualitative data, it examined social and cultural factors, family and interpersonal relationships and living arrangements and conditions. The dissemination of the findings is in process and preliminary results are integrated in this article.

Ethnic seniors must have decision-making powers regarding issues that affect them and need to be involved and represented at all level of organizations, government departments, and communities. As active participants, they will have a voice in policy, social, and program developments (CPHA, 1988).

Immigrant seniors offer a potential resource to Canadian society and methods should be developed to encourage volunteer service in agencies that provide services to ethnic groups. Sometimes volunteer service is "foreign" to some groups and efforts to develop volunteerism may be necessary. Many start by contributing to their ethnic community.

Information regarding services and programs must be accessible to ethnic seniors. Language barrier in the service agencies must be improve through the use of interpreters, translation of materials, and employing multilingual staff. Language barriers have made services inaccessible by ethnic seniors and as a result, they frequently do not receive the assistance or the information they need or are entitled to receive.

Changes need to be made in major health and social services agencies such to better serve ethnic seniors (Olson, 2001). Some of the service agencies do not meet their needs and are not culturally sensitive (Gelfand, 2003); however there are useful manuals and guidelines offering cross-cultural strategies and advice beginning to appear (See Elliot, 1999 and Fisher et al. 2000). Ironically, in most health and social agencies, the service providers from the custodial and support employees through to the professional staff are ethnically diverse. There is the need for an honest evaluation of the facilities' services. For example, one of the major issues for ethnic seniors is the inappropriate diet in long-term care facilities. Since many of these elderly are frail and immigrated under the family class, they have had little time to adjust to western life and foods. They often enter long term care in poor health and their final years are disappointing.

At times, there is a need for specialized services for special needs groups such as mental health, dementia, and end-of-life care (Butler, Lewis \& Sunderland, 1998; Fisher, Ross \& MacLean, 2000). Research on mental health and ethnic seniors is lacking, especially those who have suffered through past violence and trauma and the effects surface late in life. 
Douglas Durst

There have been changing values in filial responsibility and more immigrant seniors wish to and are living independently. To achieve independent living, many need economic security and access to support services. They may need services such as home care services, meals on wheels and day care/respite that are culturally appropriate.

Overall, the ethno-cultural seniors need to be recognized and valued for their diversity. They need to have more decision-making powers regarding policies, economics, health and social issues that affect them, and to have better knowledge about the services and programs that are available. Our diverse multicultural nation is facing new challenges with our aging population, making Canada an exciting place to live.

\section{References:}

Burton, Linda and Vern L. Bengtson, (1982). "Research in Elderly Minority Communities: Problems and Potentials," in Ron C. Manuel. (Ed.). (1982). Minority Aging: Sociological and Social Psychological Issues. Westport, CT: Greenwood Press, pp. 215-222.

Butler, Robert N., Myrna I. Lewis and Trey Sunderland, (1998). Aging and Mental Health: Positive Psychosocial and Biomedical Approaches. Needham Heights, MA: Allyn and Bacon.

Chappell, Neena L., Ellen Gee, Lynn McDonald and Michael Stones. (2003). Aging in contemporary Canada. Toronto, Ontario: Prentice Hall, Inc.

CPHA (Canadian Public Health Association). (1988). Ethnicity and Aging Report: A National Workshop on Ethnicity and Aging 21-24 February 1988. Ottawa, Ontario: Ministry of State.

Driedger, Leo and Neena L. Chappell. (1987). Aging and Ethnicity: Toward an Interface. Toronto, Ontario: Butterworths.

Durst, D. (1996). "Multicultural Research into Healthy Aging: Practical Issues and Strategies". in Research into Healthy Aging: Challenges in Changing Times. Conference Proceedings. Centre on Aging, Mt. St. Vincent University. Halifax, Nova Scotia. Nov. 7-8.96. pp. 143-157.

Freiler, C. (2001). What needs to change? Towards a vision of social inclusion for children, families and communities. Draft Concept Paper. Toronto, Ontario: Laidlaw Foundation. 
Aging amongst Immigrants in Canada: Population Drift

Fisher, Rory, Margaret M.Ross and Michael J. MacLean. (2000). A Guide to End-of-Life Care for Seniors. University of Toronto, Ontario: National Advisory Committee.

Elliot, Gail. (1999). Cross-Cultural Awareness in an Aging Society. Effective Strategies of Communication and Caring. Hamilton, Ontario: Office of Gerontological Studies.

Gelfand, Donald E. (2003). Aging and Ethnicity: Knowledge and Services. $2^{\text {nd }}$ Edition. New York: Springer Publishing Company, Inc.

Gelfand, Donald E. and Charles M.Barresi (Eds.). (1987). Ethnic Dimensions of Aging. New York: Springer Publishing Company, Inc.

Lai, Daniel W.L. (2000). "Depression Among the Elderly Chinese in Canada". Canadian Journal on Aging. 19(3), 409-429.

MacKinnon, M., L. Gien and D. Durst. (2001). "Silent Pain: Social isolation of Chinese Elders in Canada". in Iris Chi, Neena L. Chappell \& James Lubeen (Eds.). Elderly Chinese in Pacific Rim Countries: Social support and integration. Hong Kong: Hong Kong University Press, pp. 1-16.

Manuel, Ron C. (Ed.). (1982). Minority Aging: Sociological and Social Psychological Issues. Westport CT: Greenwood Press.

Manuel, Ron C. and John Reid. (1982). “A Comparative Demographic Profile of the Minority Aged and Nonminority Aged". in Ron C. Manuel. (Ed.). (1982). Minority Aging: Sociological and Social Psychological Issues. Westport, CT: Greenwood Press, pp. 31-52.

Markides, Kyriakos S.and Charles H. Mindel. (1987). Aging and Ethnicity. Newbury Park, CA: Sage Publications, Inc.

Novak, Mark. (1997). Issues in Aging: An Introduction to Gerontology. New York: Addison-Wesley Publishers Inc.

Olson, Laura Katz, Ed. (2001). Age Through Ethnic Lenses: Caring for the Elderly in a Multicultural Society. Oxford, UK: Rowman \& Littlefield Publishers, Inc.

Schaie, K. Warner and Sherry L. Willis. (1996). Adult Development and Aging. $4^{\text {th }}$ Edition. New York: HarperCollins Publishers Inc. 
Douglas Durst

Statistics Canada. (2005). http://www.statcan.ca/english/Pgdb/popula.htm\#imm; http://www12.statcan.ca/english/census01/products/standard/themes/

Stone, Leroy O. and Susan Fletcher. (1980). A Profile of Canada's Older Population. Montreal, Quebec: The Institute for Research on Public Policy.

Suzman, R. and M. W. Riley. (1985). "Introducing the 'oldest old'”. Milbank Memorial Fund Quarterly: Health and Society. 63, pp. 177-185.

Ujimoto, K. Victor (1987). "The Ethnic Dimension of Aging in Canada". In Victor W. Marshall (Ed.). Aging in Canada: Social Perspectives. $2^{\text {nd }}$ Edition. Richmond Hill, Ontario: Fitzhenry \& Whiteside, pp. 111137. 